\title{
〔特集〕成熟社会における住宅宅地政策の方向と課題
}

論説

\section{新たな住宅政策の方向性について \\ 一住宅宅地審議会答申をもとに一 \\ New directions of Housing Policy in Japan \\ On the Report of Central Housing and Land Council}

Professor DR Shigenori KOBAYASHI : Faculty of Engineering, Yokohama National University 小林 重敬*

The Report of Central Housing and Land Council stated some new directions of Housing Policy in Japan in June 2000 .

The Report stated many important changes of housing policy from housing policy in growth society to housing policy in matured society.

A main purpose of housing policy in growth society had given the first priority to lead households to own their own houses.

But a main purpose of housing policy in matured society will change to lead households to make use of houses.

To make such radical changes, the report put stress two points; we think of making use of market mechanism important and of the quality of housing stock important.

Keywords : Housing Policy, Growth Society, Matured Society, Market Mechanism, Housing Stock 住宅政策, 成長社会, 成熟社会, 市場機能, 住宅ストック

平成 12 年 6 月に住宅宅地審議会は 21 世紀に展 開すべき住宅政策の方向性について，これまでの 住宅政策とは考え方を大きく転換したものとして 答申した。以下ではこの答申をべースとしながら， 多少の私見を交えて，これからの住宅政策の方向 性について述べることとする。

\section{1.これまでの住宅事情をめぐる背景}

答申は住宅政策を体系的に転換する背景を, 成
長社会から成熟社会への移行とし，これまでの成 長社会での住宅政策の基調を持家中心の構造とし て描いている。

すなわち成長社会では，地価が継続的に上昇す るため, 住宅取得行動が土地の取得に強い関心を 持ち，結果として住宅自体に対する資金配分が十 分でないものとなっていたことをまず述べている。

さらにその住宅取得行動は土地取得を最終目的 とするため，一戸建て持家を最終の目的とする

*小林 重敬（こばやししげのり）・正会員 横浜国立大学工学部 
「住宅双六」による居住水準の向上が図られた。そ のような行動を支えたのが，わが国特有の年功序 列型賃金体系による長年月務めることによる賃金 の上昇という賃金体系であった。

また「住宅双六」のプロセスの途上にある賃貸 住宅は「仮の住まい」という性格を持たされ，賃 貸住宅自体の水準向上に一定の制約となった。さ らに持家を取得する際には土地の取得に資金の配 分の重点を置くためを，住宅自体に対する資金配 分が十分でない新築住宅市場と, 欧米に比較して 極端に建て替え周期の短い建て替え市場がつくら れていった。

その結果が，持ち家を中心とする新築建て替え 中心の住宅市場構造であり，逆の面からも見れば 中古, リフォーム, 賃貸住宅市場の未整備, 未成 立である。

また成長社会は有利な働く場を確保するため, 若年層が大都市への移動を行う社会でもあり，大 都市, 中でも郊外部に大量の住宅供給が図られた。

答申で述べる成長社会から成熟社会への移行は, 一方で近代社会から次の社会 (ポストモダン社会) への移行でもあり，家族や世帯と深い関係にある 住宅政策としてはその面からの考察も必要となる と考える。

核家族の出現や男女役割区分の出現は近代社会 の特徴であり，そのことがわが国における郊外部 での持ち家を中心とした住宅供給の必要性を強め た。すなわち核家族化は新たな住宅地供給を必要 とし, 男女役割区分は男性が都市中心部で働き, 女性は郊外部の住宅で子育てを行うという仕組み を作り，それを都市計画の機能分離ツールである 用途規制が間接的に担保することになった。

その結果が, 新規の大規模ニュータウンを含め て, 画一的, 単機能的な郊外住宅地の出現である。

\section{2. 成長社会, 近代社会の構造がもたらし た住宅事情}

1 で述べたようなわが国の住宅政策をめぐる経
済社会環境は, 結果として次のような住宅事情を 住宅政策の上で残すこととなった。

\section{(1)持家を中心に住宅床面積の拡大}

持ち家を中心に住宅の平均床面積が着実に向上 し, 着工新設住宅の中で, 持家の 1 戸あたりの平 均床面積は平成 11 年度で $139.3 \mathrm{~m}^{2}$ となっている。 その結果, 持家階層の人々の家に対する関心は, 住宅の広さから性能, 設備等に移っていると考え られる。

\section{(2)借家の居住水準は依然低水準}

持ち家を中心に住宅の平均床面積が着実に向上 する一方で, 借家の居住水準は依然低水準にある。 着工新設住宅の中で, 借家の 1 戸あたりの平均床 面積は平成 11 年度で $53.2 \mathrm{~m}^{2}$ となっている。その 結果, 借家に対する不満が増大していると考えら れる。

(1)と(2)は着工ベース，すなわちフローベースの 状況であるが，それをストックベースで見てみる とさらに事情が鮮明になる。平成 5 年度の住宅統 計調査からのデータである図ー 1 に見るように, 住宅ストックの全国規模分布は持家では 120 $149 \mathrm{~m}^{2}$ に最頻值があるのに対して，借家では30〜 $39 \mathrm{~m}^{2}$ との持家の 3 分の 1 程度である。

\section{(3)大都市圏の住宅ストックと住環境は低水準}

(1)と(2)は全国べースの住宅の状況であるが，大 都市圈においては戦争直後とそれに引き続く高度 成長期の住宅不足の時代に建設された住宅ストッ クが大量に存在し, 老朽化と陳腐化が進行してい る。また住宅不足の時代に無秩序な市街地拡大が 郊外部で展開し, 防災上危険な密集市街地が多数 存在する。大都市圈の密集市街地の住環境改善の 必要性が増大している。

また密集市街地のさらに外側に展開する郊外住 宅市街地は, 一団の住宅市街地としての一定の質 を満たしているところも多いが，同じような戸建 て住宅が連続する単調な住宅地であることや, 通 勤通学時間の増大が指摘されている。そのような 状況の中で, 改めて職住近接の必要性が高まって 
いる。

\section{(4)少子・高齢化の急激な進行と居住に対する不安}

近代社会が生み出した核家族という家族文化が 初めて経験する高齢化が進行中であり，高齢期の 新たな住まい方が模索されており，多くの人々の 不安の種となっている。また女性の社会参画や晚 婚化の傾向が少子化の動向を促し，住宅政策とし ての対応が模索され, これも人々の不安の種とな っている。

\section{3，住宅事情をめぐる背景の変化}

これまでの住宅政策の背景となってきた成長社 会や近代社会の枠組みが，今日大きく失われてき ている。成熟社会やポストモダン社会への移行で ある。

成長に伴う地価の上昇がおわり，地価は安定化 し，下落をしている。経済成長率も鈍化し，マイ ナスを記録している。その結果，年功序列型賃金 体系を維持してきた日本型雇用慣行も限界を迎え ている。

その結果，これまでの土地取得に強い関心を持 った住宅取得行動は終わりを告げようとしている。

またポストモダン社会は多様な価值観を際だた せ, 家族形態の多様化が進行し, さらに男女役割

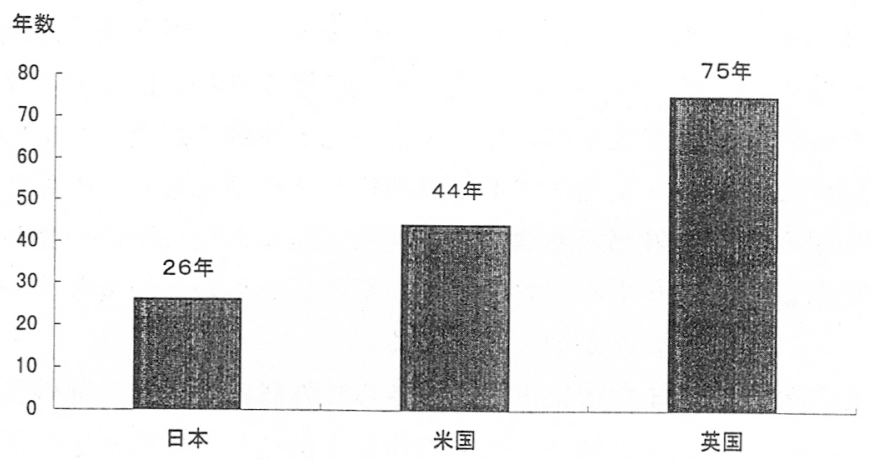

注) 平均䨛用年数: 滅失住宅について、隇失までの期間を推計

資料 日本: 住宅統計調査(1988年、1993年)

米国: American Housing Survey(1987年、1993年)

英国: Housing and Construction Statistics(1981年、1991年)

図 1 住宅の平均耐用年数の国際比較
の変化にともなう女性の社会進出が一般的になり, これまでの都心のオフィスで働き, 郊外部の住宅 市街地で居住するというスタイルは単なる 1 類型 になると考える。その結果，既成市街地内での住 宅と他の機能とのバランスの取れた機能複合が要 請されてくるものと考える。

また地球環境問題からくる環境制約も，住宅政 策をめぐる新しい社会背景の一つであると考える。

\section{4.これからの新たな住宅政策の方向（住宅 宅地審議会答申をベースに)}

\section{(1)成熟社会における住宅政策の課題}

先に述べたように成長社会における住宅取得行 動は土地取得とそれに付随する持家取得を最終の 目的とする「住宅双六」により，居住水準の向上 が四られた。

しかし成熟社会における居住水準の向上には 「市場を通じて国民が共有しうる良質な住宅ストッ ク（社会的な資産）を形成し，管理し，円滑に循 環させることができる新しい居住水準向上システ ム」が求められることになる。

そのためには住宅を取得することに住宅政策の 重点を置くのではなく，住宅を居住サービスを生 み出すものとして位置づけことが重要である。そ のためには現在の住宅ストックを，長 期耐用性，環境との共生，長寿社会への 対応等に配虑したものへと再生するこ とが重要である。そのためには新規住 宅供給と既存ストックの活用の雨面で の政策が必要であり，ストックの流動 性を高め，「居住」に関する多様な選択 肢を提供する必要がある。それは多様 な家族形態，その源にある価值観の多 様化に伴う居住ニーズの多様化に対応 し，既存ストック活用を通して環境制 約に対応するものである。

\section{(2)重視すべき視点と基本的方向}

上記のような成熟社会における住宅 
政策を進めるために必要な視点として 2 つの視点 が挙げられる。

(1)市場重視

「国民の多様な居住ニーズを効率的に満たすシ ステムを構築するため，市場における選択を原則 とし，市場の関わりにおいて政策を構成するス タンス」

\section{(2)ストック重視}

「住宅ストックが量的に充足している現状，成 熟社会がもたらすさまざまな制約を勘案し，耐久 性の高い良質の住宅ストックを形成し，それを維 持管理, 循環させていく等, 住宅ストックの質, 流 動性との関わりにおいて政策を構成するスタンス」

\section{5. 新たな住宅政策体系への転換の基本的 方向}

これまでの住宅政策から，新たな住宅政策体系 への転換を図るためには，以下の 5 つの基本的方 向が重要であるとして，さらに，その具体的な方 向を示している。

(1)良質な住宅ストック・居住環境への再生

(2)既存ストック循環型市場の整備による持続可
能な居住水準向上システムの構築

(3)少子・高齢社会に対応した「居住安全システ 厶」の確立

(4)ストック重視。市場重視の住宅政策体系を支 える計画体系の再編

(5)成熟社会の住宅政策を支える公民の役割分担

\section{6. 新たな住宅政策体系への転換の具体的 方向}

\section{(1)良質な住宅ストック・居住環境への再生}

高度経済成長期ストックの更新等を契機とした 住宅ストック全体の改変を図る必要がある。

そのために第 1 に新築住宅市場などを通して高 度化し，多様化した国民のニーズに応える新築住 宅市場の環境整備とそれによる良質ストックの提 供が重要である。

第 2 にストック社会, 循環型社会にふさわしい 住宅ストックの新たな更新，維持管理のあり方が 課題となる。すなわち住宅ストック（公的賃貸住 宅ストック, マンションストック, 賃貸住宅スト ック）の新たな更新，維持管理の方策である。

第 3 に都市の居住地再生である。都市・地域に おける居住地再生するため, 都 心居住の推進, 密集市街地の整 備等を通した都市居住再生, 地 域活力の維持増進が必要である。 また，新たな社会経済潮流に対 応する住宅の新規形成方策が必 要である。例えばSOHOやコー ポラテイブ住宅などである。

第 4 に交流居住など多様な二 一ズに応える新たな地域居住の 創造のために，地方都市中心市 街地での住宅供給や中山間地で の定住住宅供給を図る必要があ る。それは都市と地方を連携す るマルチハビテーションなどへ の支援を図ることにつながる。 
上記のような施策を進めるには，良質なストッ ク誘導型の税制や融資の構築が必要である。また 都市基盤整備公団，住宅金融公庫，住宅供給公社 の活用が重要である。

(2)既存ストック循環型市場の整備による持続可能 な居住水準向上システムの構築

第 1 に中古住宅市場の活性化への取り組みであ る。そのためには履歴情報活用システムの整備, 分譲マンションの管理に係わる登録制度の構築, 性能評価・履歴情報等を活用した市場評価の実現 が図られる必要がある。

第 2 に貨貸住宅市場の活性化への取り組みであ る。そのためには定期借家制度の導入などを踏ま えた相談機能の充実と市場ルールの明確化，賃貸 住宅経営・管理の業としての適正化・多様化, 企 業による賃貸住宅市場への参画が図られる必要が ある。

第 3 にリフォーム市場の活性化への取り組みで ある。そのためには多能工の育成による施工の合 理化, 部品の標準化による個人によるリフォーム 等の実現, リフォーム市場へのアクセスの向上の ために標準書式の整備などを図る必要がある。

(3)少子高齢社会に対応した「安心居住システム」 の確立

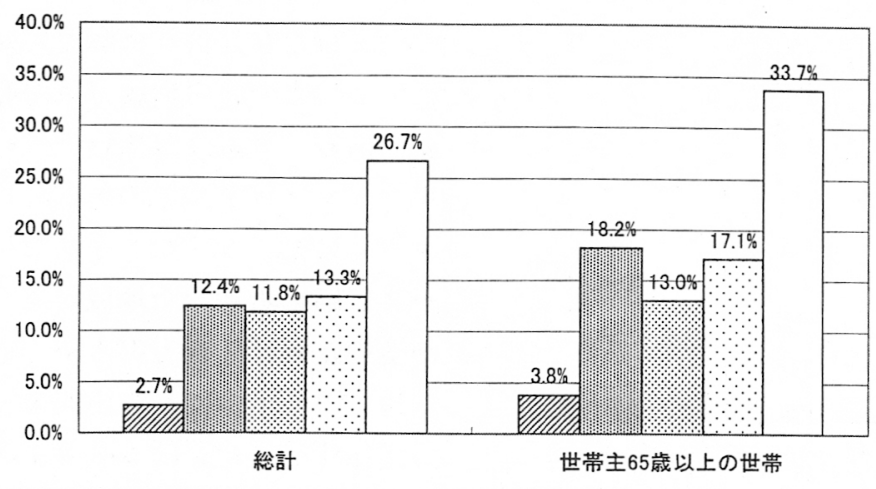

凹手すり、段差、通行幅すべて 图手すり 回段差 『通行幅 ロどれか一つ備えている

出典）「平成10年住宅需要実態調査」(建設省住宅局)

図 3 高齢者対応の状況
第 1 に持家住宅のバリアフリー化等の促進であ る。そのためには相談体制の構築，融資の活用な どが考えられ，さらリバースモーゲージを活用し たリフォームの促進が挙げられている。

第 2 に問題が多い民間賃貸住宅を高齢者対応型 にするための制度構築である。そのための供給支 援システムの構築，家賃保障システムによる高齢 者入居の担保などが挙げられている。

第 3 に高齢化に対応した公共賃貸住宅政策の充 実によるセーフテイーネットの構築である。

そのためには公共賃貸住宅のストックの改善, グループ居住のためのストック形成, 在宅介護の 場としての公共賃貸住宅ストックの形成などが挙 げられている。

第 4 に家族の子育て負担を軽減する良質な住宅 ストック形成である。

\section{(4)ストック重視, 市場重視の住宅政策を支える計 画体系の再編}

今後，長期的視点に立ち，良質ストックの形成， 維持及び円滑なストック循環を実現するための施 策を計画的に推進することが必要であるとし，そ のための計画体系として 3 点を挙げている。

第 1 に新築, 建て替え, リフォーム等の「スト ック整備」に係わる施策のプログラムとそれによ って目指す「住宅ストックの姿」を想定 すること。

第 2 に市場整備等「ストック循環」の 推進に係わる施策プログラムを策定す ること。

第 3 に第 1 と第 2 によって目指す 「居住水準の姿」を示すこと。

さらに新たな居住水準のあり方とし て住宅性能の水準をできる限り明示す ることを指摘している。また新たな住 環境水準のあり方として「緊急に改善 すべき密集住宅市街地」の基準を国と して示す一方，地方公共団体に施策展 開の指針となる「住宅市街地の改善・向 
上等の指針」を定めることを求めている。

\section{7. 新たな住宅政策を支える公民の役割分 担}

まず公的主体の役割として, 市場の環境整備, 市場の補完，市場の誘導が示されている。さらに 地方の独自性, 自主性の発揮と福祉行政との連携 に代表される総合的な行政領域における施策展開 の必要性が指摘されている。

また今後の住宅政策は多様な主体によって推進 が必要であるとされ，住宅金融公庫の活用，都市 基盤整備公団の活用，地方住宅供給公社の業務展 開の今後への期待，さらに民間事業者，NPOの活 用と連携が求められている。

\section{おわりに}

今回の答申には市場の重視とストックの重視が 基調としてうたわれている。単に市場の重視でな くストックの重視を対として指摘していることに 注意する必要があると考える。

それは田中直毅氏がその著書「新しい産業社会 の構想」(日本経済新聞社 1996年)で述べている 次のような言葉と関係する。田中氏は「市場経済 の原理を徹底させることだけでは, 来るべき社会 は見えてこない。いわば, 社会の奥行きの部分で 伝統に受け継がれてきた「遺伝子」の部分が，市 場原理と並ぶ形で, 新たな社会を生み出すのでは ないか」，そして，この社会の奥行きの部分を持っ
ている社会は「深い社会」であり，「市場を媒介し ない一人一人の個人の社会への寄与が，この「深 い社会」のつながりを支えることになるのではな いか。と述べているのである。

先に述べたように答申は，重視すべき視点とし て市場重視と並んで，ストック重視を打ち出して いるが，このストック重視の視点は，田中氏の言 う「社会の奥行きの部分で伝統的に受け継がれ」, 市場原理と並んで，新たな社会を生み出す視点と なるのであろうか。そのことにつながる言葉を， 答申に求めるとすると次のような言葉に行き当た る。

「市場を通じて国民が共用しうる良質な住宅スト ック（社会的な資産）を形成し，管理し，円滑に 循環させることが出来る新しい居住水準向上シス テムの構築」と言う言葉である。

この「社会的な資産を形成し，管理し，円滑に 循環する」システムを構築するには，一人一人の 個人や一つ一つの企業の社会への寄与が必要であ り，その様な機運を生み出す「社会の奥行き」が 必要である。すなわち住宅が「市場を通して国民 が共用しうるものである」という認識があり，さ らにそのような認識にいたるには, 答申の基調と なっている，住宅の中古市場，リフォーム市場を 活性化することが，持続可能性の高い社会を生み 出し, 地球環境などの環境問題に寄与することで あるという思いが必要である。 


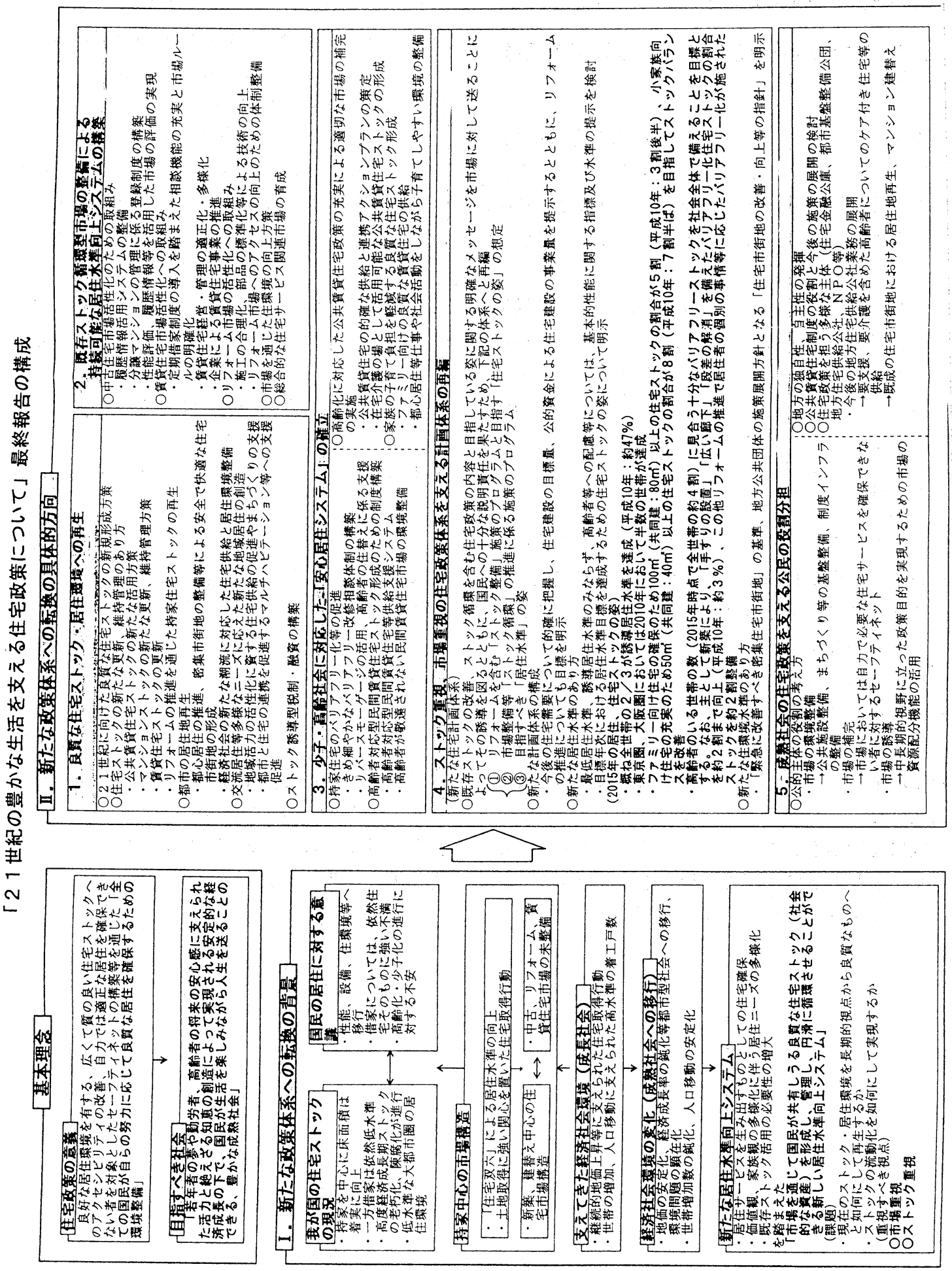

